\title{
Nature-Related Experience during Childhood in Urban and Rural Areas: The Case of Peninsular Malaysians
}

\author{
Huda Farhana Mohamad Muslim, ${ }^{1,2}$ Tetsuro Hosaka, ${ }^{1}$ Shinya Numata, \\ and Noor Azlin Yahya ${ }^{2}$ \\ ${ }^{1}$ Department of Tourism Science, Graduate School of Urban Environmental Science, Tokyo Metropolitan University, \\ 1-1 Minami Osawa, Hachioji, Tokyo 192-0397, Japan \\ ${ }^{2}$ Forest Research Institute Malaysia (FRIM), 52109 Kepong, Selangor, Malaysia
}

Correspondence should be addressed to Huda Farhana Mohamad Muslim; ladyfarhana@gmail.com

Received 15 June 2017; Accepted 11 July 2017; Published 10 August 2017

Academic Editor: Thomas Panagopoulos

Copyright (c) 2017 Huda Farhana Mohamad Muslim et al. This is an open access article distributed under the Creative Commons Attribution License, which permits unrestricted use, distribution, and reproduction in any medium, provided the original work is properly cited.

\begin{abstract}
Direct experiences with nature in childhood are essential for enhancing psychological and physical development in children. However, researches on childhood nature-related experiences and their effects are largely biased toward more developed Western countries. In this study, we created a questionnaire on childhood experiences with nature and surveyed 357 adults ( $>20$ years old) around Kuala Lumpur, the capital of Malaysia, to determine whether younger generations had fewer nature-based experiences than older generations and whether people who grew up in urban areas had fewer experiences than those who grew up in rural areas. We found that playing in rivers or waterfalls and collecting and eating tropical fruits were the most common nature-related activities experienced in childhood. There was a minimal decline in nature-related experiences among generations. However, people who grew up in rural areas had more nature-related experiences than those who grew up in urban areas. The loss of nature areas and increase in population density may accelerate the decline in nature-related experiences in urban areas. Therefore, efforts to create urban parks and other public spaces for reconnecting urban children to nature will become increasingly important for urban planning and environmental education in tropical developing countries such as Malaysia.
\end{abstract}

\section{Introduction}

More than half of the global population lives in cities. As such, urban biodiversity conservation must be utilized to prevent the "extinction of experience" cycle, whereby people who do not have the opportunity to interact with nature are less likely to value and appreciate nature, leading to a decline in public support for conservation activities and further degradation of natural environments $[1,2]$.

Direct experiences with nature have substantial positive impacts on the mental, emotional, and social development of children [3, 4] and people's behavior [5] and can encourage healthy lifestyles [6-9]. Experience with nature in childhood is particularly important for cultivating proenvironmental attitudes, behaviors, and moral judgments later in life [10-14]. For example, Lohr \& Pearson-Mims [15] found a significant association between adult attitude toward natural entities such as trees and nature-based practices like gardening with childhood nature experiences. In addition, positive experiences with nature during childhood are major motivators in adult environmentalists to protect the environment [14, 16, 17]. Therefore, in the current "extinction of experience" era, it is important to understand how children relate to nature and how this connection has changed over time and among various sociodemographics. This is particularly urgent in developing countries experiencing rapid urbanization. However, our understanding of childhood nature-related experiences is largely biased toward more developed Western countries. Southeast Asia is a rapidly urbanizing region that has experienced drastic changes in and degradation of natural landscapes in the past few decades (e.g., [18]).

Within Southeast Asia, Malaysia is one of the more rapidly developing and urbanizing countries, while being recognized as one of 12 megadiverse countries in the world 
[19]. Its population grew from 14 million in 1980 to 30 million in 2015 [20]. The forested area in Peninsular Malaysia declined from $73 \%$ in the late 1960 s to $44 \%$ in 2001 [21, 22]. Meanwhile, built-up areas and agricultural areas increased from $1 \%$ to $3 \%$ and $24 \%$ to $51 \%$, respectively [21, 22]. This increase in agricultural land was mainly due to the rapid expansion of oil palm plantations [23], in which local children do not usually play. Consequently, the percentage of the urban population to the total population increased from $-10 \%$ in 1911 and $28 \%$ in 1970 to $62 \%$ in 2000 [24]. Because the availability of natural environments is a key element enabling children to interact with nature [4], these rapid changes in land use and urbanization from 1960 to 2000 have likely caused a decline in childhood experience with nature among Malaysians.

We hypothesized that younger people experienced fewer childhood nature-related activities than older people and that the declining trend is more obvious among children in urban areas than those in rural areas. Moreover, fundamental information on the type of nature activities in which Malaysian people have actively involved in their childhood is still limited. Therefore, in order to document popular nature activities in childhood and to test the hypotheses above, we conducted a questionnaire survey of 357 adult residents around Kuala Lumpur on their experience with naturerelated activities in childhood. We addressed the following research questions:

(1) What are common nature-related activities during childhood among Malaysians?

(2) Do younger generations experience fewer naturerelated activities than older generations?

(3) Does the level of childhood nature-related experiences differ between people who grew up in rural areas and those who grew up in urban areas?

To our knowledge, this is the first study to document common childhood nature-related experiences in Malaysia and temporal changes in nature-related experiences.

\section{Research Methods}

2.1. Study Area. Malaysia has a typical tropical monsoon climate, with temperatures ranging from $23^{\circ} \mathrm{C}$ to $32^{\circ} \mathrm{C}$. According to the National Biodiversity Index, Malaysia is one of 12 megadiverse countries in the world [25]. Most the country is covered with rainforest, which is host to numerous plant and animal species [26]. Before its independence in 1957, the Malaysian economy was heavily dependent on primary products. The Malaysian government promoted rubber plantations from 1900 until the 1950s and oil palm plantations since the 1960s. In addition, it promoted the manufacturing sector with the aim of diversifying the agriculture-based economy and generating employment opportunities. More recently, industrialization has become important for achieving the New Economic Policy, in particular the restructuring of employment and ownership of assets, as well as the alleviation of poverty [27]. Urban development in Peninsular Malaysia began in the early 1980 s to the 1990 s via manufacturing and industrialization [28, 29]. Rural areas in 1970-2000 are comprised of farms, plantations, paddy fields, rubber estates, oil palm plantations, orchards, and home backyards.

2.2. Questionnaire Survey. The questionnaire survey was conducted in three rural districts (Hulu Langat, Kuala Selangor, and Hulu Selangor) and three urban towns (Kepong, Kuala Lumpur, and Putrajaya) in and $<100 \mathrm{~km}$ from Kuala Lumpur, the capital of Malaysia. In this study, urban was defined as nonagricultural areas with $>10,000$ inhabitants, while rural areas were defined as areas consisting mainly of agricultural and forested lands or water bodies with $<10,000$ inhabitants $[30,31]$. This study is part of a greater body of research assessing attitudes toward green spaces and wildlife and experiences in nature-related activities among Malaysian people. The questionnaire consisted of four main sections: perceptions toward green spaces and wildlife, perceptions toward policies and governance of green spaces, sociodemographic characteristics (i.e., gender, age, education level, ethnicity, has/does not have children, annual income, and urban/rural childhood setting), and experiences with naturerelated activities in childhood.

To assess their experiences with nature-related activities in childhood, we asked adults' respondents whether they had experienced each of 18 activities ("yes" or "no") when they were children ( $\leq 12$ years). The nature activities included were playing in rivers and waterfalls, observing wild animals, collecting flowers and fruits, collecting seeds and twigs, eating self-collected fruit, climbing trees, making kites, fishing, sliding river banks and slopes, playing with soils or sands, making spinning top, making a flower crown, collecting herbs and weeds, catching frogs or spiders, making a bamboo gun or a boat from bamboo, and participating in traditional outdoor games. These activities were selected based on discussion with experts, including local environmental educators, and the website "Malaysia games without gadgets" [32], because they have probably been common among Malaysian children during the past 50 years or longer $[33,34]$. We only included activities that involved direct interactions with plants, animals, or soil. We did preliminary survey before the main survey to confirm that the activities are relevant for all generations.

2.3. Survey Procedure. In January to March 2016, we visited randomly selected houses in the six study areas and conducted a face-to-face interview with one adult member ( $>20$ years) at each household following the structured questionnaire. The survey was conducted in either English or Malay. We targeted 180 respondents in each area. No names and identification numbers were collected from the respondents.

2.4. Survey to School Children. In addition to the survey to the adults, we also conducted another questionnaire survey to know current nature-related experiences of school children. The survey to school children was carried out in November 2016. In total, 401 (female $=193$, male $=208$ ) of school children from 4-6 grades, aged 10-12 years old 


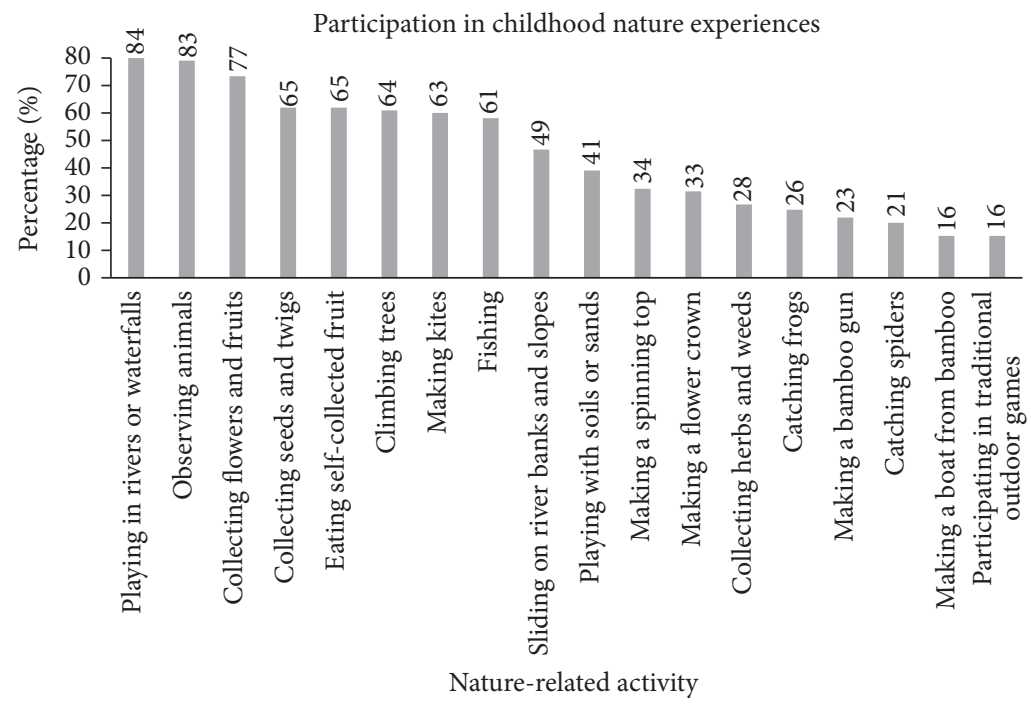

FIGURE 1: Percentages of respondents who experience each activity in childhood $(n=357)$.

were surveyed. In the survey, we provided the similar naturerelated activities with adults' survey that involved direct interactions with plants, animals, or soil to assess the school children experiences. We also asked their frequency $(1=$ never, 2 = seldom, $3=$ sometimes, and $4=$ often) of nature activities for the 18 activities. The frequencies of the children's activities corresponds to "less than once a month," "almost every month," "almost every week," and "almost everyday," respectively.

2.5. Data Analysis. To identify common nature-related activities among current children and past generations' children in Malaysia, the percentage of respondents who had experienced each activity has been calculated. To identify influential factors on childhood experience, a generalized linear mixed model (GLMM) with a binomial error distribution and loglink function was used. The input response variables included experience (yes $=1$; no $=0$ ) or the total number of activities experienced ( 0 : experienced none of the activities to 18: experienced all of activities). Fixed variables were gender (female $=0$; male $=1$ ), age $(20-39=$ young, $40-59=$ middleaged, and $\geq 60=$ old), and childhood setting (rural $=0$; urban $=1$ ). The age-variables were divided into 3 categories rather than using them as continuous variables since it found that the relationships between age and the level of activities were often nonlinear. Since we expected a different temporal trend in the level of nature activities, thus we included an interaction between age and childhood setting was included in the model. The random effects used was "area ID" and the GLMM was performed with the lme4 package in R ver. 3.1.2 [35].

\section{Results}

3.1. Sociodemographics Profile. A total of 357 responses obtained, of which 180 were in urban areas and 177 were in rural areas. Females accounted for $70 \%$ of respondents in urban samples and 50\% in rural samples. Overall, 63\% of all respondents grew up in rural areas in childhood. The most common responses in each sociodemographic category were middle-aged, having a child, moderate income (4,500-7,900 USD/year), and completed lower secondary school. Regarding ethnicity, $86 \%$ of respondents were Malay, although only $60 \%$ of the total population is Malay, while Chinese and Indian account for approximately 30\% and 10\% of the total population, respectively. Therefore, it should be noted that this study is biased towards Malay people.

\subsection{Childhood Nature-Related Experiences}

3.2.1. Common Nature-Related Activities in Childhood. To investigate our first research question, we measured the percentage of adults and the current school children naturerelated experiences. Of the 18 nature-related activities included in the adult's survey $(n=357)$, playing in rivers and waterfalls was the most common (experienced by $84 \%$ of respondents), followed by observing animals (83\%), collecting flowers and fruits (77\%), collecting seeds and twigs (65\%), and eating self-collected fruit (65\%) (Figure 1). Meanwhile, collecting herbs and weeds (28\%), catching frogs (26\%), catching spiders $(21 \%)$, and making a boat from bamboo (16\%) were the least common activities.

3.2.2. Current Nature-Related Activities of School Children. Of the 18 nature-related activities included in the school children survey $(n=401)$, observing animals (experienced by $97 \%$ of children), collecting flowers and fruits (95\%), and playing rivers or waterfalls ( $87 \%$ ) were common (Figure 2 ). In contrary to the adults, collecting herbs and weeds (71\%) was relatively common for the school children comparing to the adults. Meanwhile, catching frogs (21\%), making a bamboo gun (19\%), and making a boat from bamboo (19\%) were the least common activities participated for the school children. 
Participation in childhood nature experiences

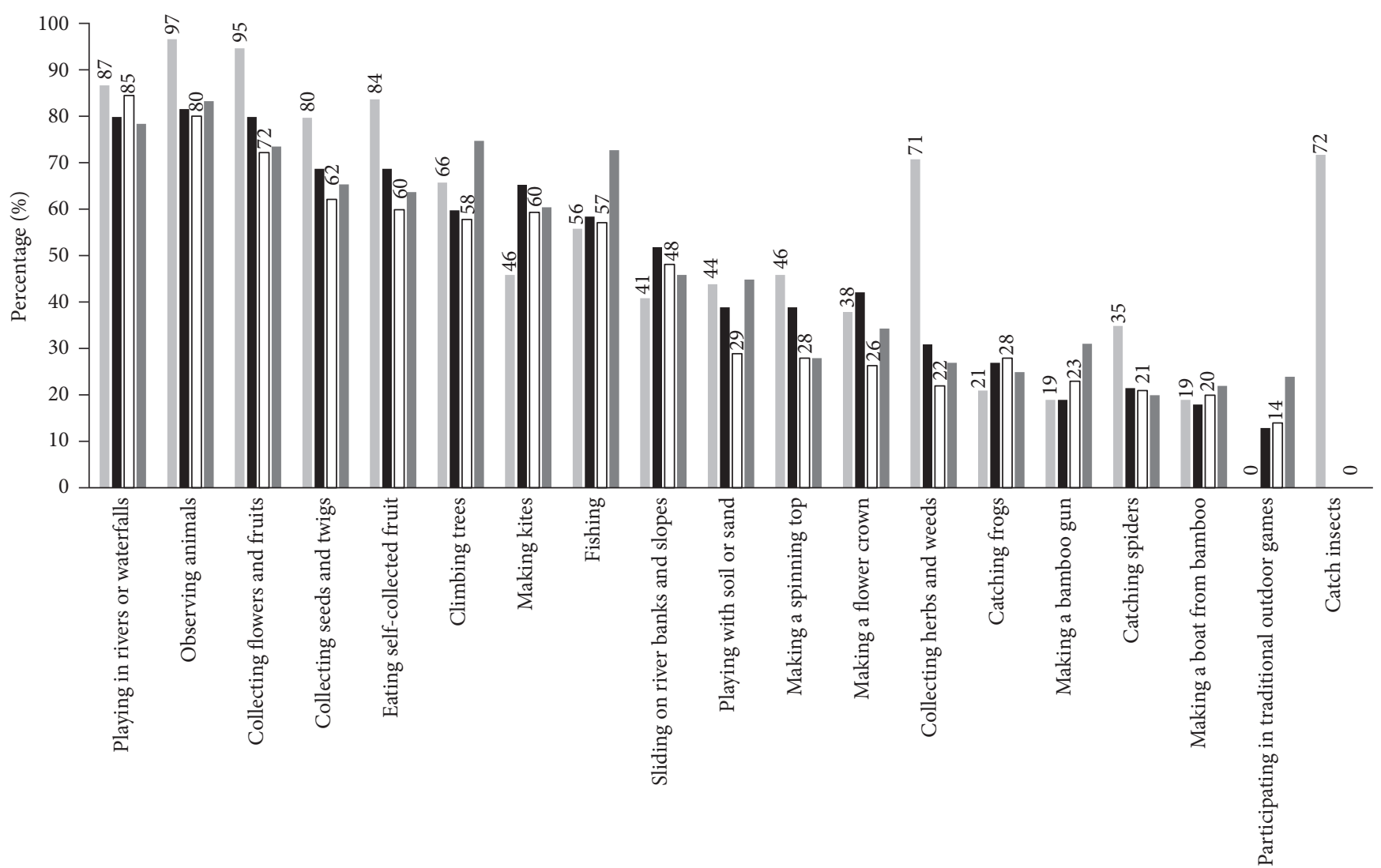

Nature-related activity

"Children
口 Middle
- Young

- Elderly

Figure 2: Percentages of present school children and adults' respondents who experience each activity in childhood.

3.3. Effects of Sociodemographics Factors. To answer the second and third research questions, we used GLMM analysis presented in Table 1 and Figure 3. The GLMM analysis revealed that the number of activities experienced in childhood was significantly greater for older people (mean \pm standard deviation: $9.2 \pm 0.2)$ than younger $(8.1 \pm 0.2)$ and middle-aged people $(8.8 \pm 0.2)$, significantly greater for people who grew up in rural areas $(9.2 \pm 0.3)$ than those who grew up in urban areas $(7.8 \pm 0.2)$ in childhood, and significantly greater for males $(9.1 \pm 0.2)$ than females $(7.7 \pm$ $0.3)$.

In the analyses of each activity, childhood setting was a significant factor for six activities (Table 1), all of which were experienced more by people who grew up in rural areas than urban residents. Gender was a significant factor for 14 activities, all of which were experienced more by males than females, except making a flower crown. Age was only significant for two activities; older people had climbed trees and participated in traditional outdoor games as children. Interaction between age and childhood setting was significant for the total number of nature-related

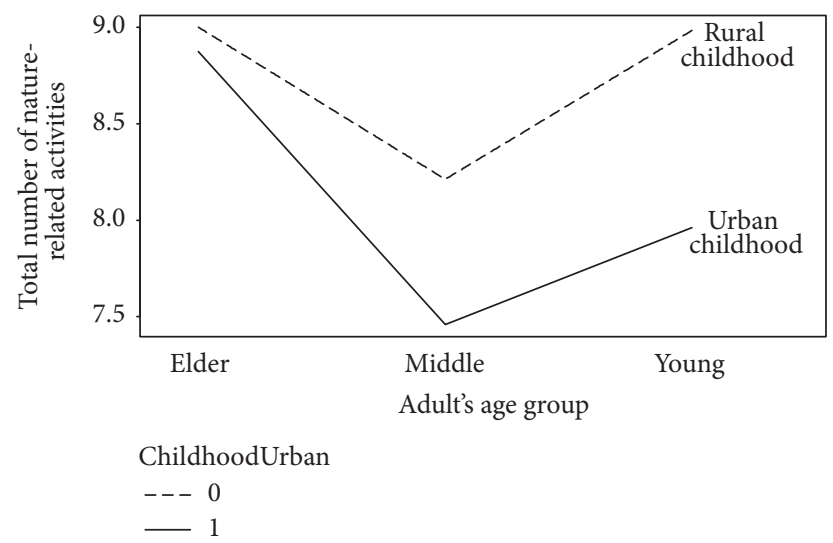

FIGURE 3: Interaction plot on age and childhood setting effects to the nature-related experience.

experiences (Table 1 and Figure 3). This suggests more rapidly declining in nature-related activities of middle-aged and young people in urban setting than those lived in rural. 
TABLE 1: Estimated parameter coefficients and standard errors (in parentheses) of the GLMM of the relationships between the experience with each activity and sociodemographic factors.

\begin{tabular}{|c|c|c|c|c|c|c|c|}
\hline \multirow{2}{*}{ Number } & \multirow{2}{*}{$\begin{array}{l}\text { Nature-related } \\
\text { activity }\end{array}$} & \multirow{2}{*}{ Constant } & \multirow{2}{*}{ Gender (male) } & \multirow{2}{*}{$\begin{array}{c}\text { Childhood } \\
\text { home (urban) }\end{array}$} & \multicolumn{2}{|c|}{ Age } & \multirow{2}{*}{$\begin{array}{c}\text { Age } \times \text { childhood } \\
\text { home (interactions) }\end{array}$} \\
\hline & & & & & Young & $\begin{array}{l}\text { Middle- } \\
\text { aged }\end{array}$ & \\
\hline 1 & $\begin{array}{c}\text { Observing } \\
\text { animals }\end{array}$ & $\begin{array}{c}1.848^{* *} \\
(0.841)\end{array}$ & $\begin{array}{c}-0.082 \\
(0.308)\end{array}$ & $\begin{array}{l}0.478 \\
(0.325)\end{array}$ & $\begin{array}{l}-0.205 \\
(0.444)\end{array}$ & $\begin{array}{c}-0.599 \\
(0.464)\end{array}$ & 0.209 \\
\hline 2 & Climbing trees & $\begin{array}{c}1.575^{* *} \\
(0.588)\end{array}$ & $\begin{array}{c}1.330^{* * *} \\
(0.302)\end{array}$ & $\begin{array}{c}-\mathbf{0 . 8 3 8}^{* * *} \\
(0.272)\end{array}$ & $\begin{array}{c}-1.304^{* *} \\
(0.443)\end{array}$ & $\begin{array}{c}-\mathbf{1 . 0 3 3}^{* *} \\
(0.469)\end{array}$ & $-0.580^{* *}$ \\
\hline 3 & Fishing & $\begin{array}{c}0.968^{* *} \\
(0.348)\end{array}$ & $\begin{array}{l}\mathbf{0 . 5 4 2}^{*} \\
(0.247)\end{array}$ & $\begin{array}{c}-\mathbf{0 . 6 8 7 ^ { * * }} \\
(0.238)\end{array}$ & $\begin{array}{l}-0.363 \\
(0.373)\end{array}$ & $\begin{array}{l}-0.576 \\
(0.347)\end{array}$ & 0.438 \\
\hline 4 & Catching frogs & $\begin{array}{c}-1.409^{* * *} \\
\quad(0.351)\end{array}$ & $\begin{array}{c}\mathbf{0 . 8 2 7}^{* *} \\
(0.261)\end{array}$ & $\begin{array}{l}-0.068 \\
(0.267)\end{array}$ & $\begin{array}{c}0.118 \\
(0.380)\end{array}$ & $\begin{array}{c}0.015 \\
(0.349)\end{array}$ & 0.103 \\
\hline 5 & Catching spiders & $\begin{array}{c}-1.699^{* *} \\
(0.382)\end{array}$ & $\begin{array}{c}\mathbf{0 . 7 9 2}^{* *} \\
(0.282)\end{array}$ & $\begin{array}{l}-0.294 \\
(0.293)\end{array}$ & $\begin{array}{c}0.288 \\
(0.409)\end{array}$ & $\begin{array}{c}0.023 \\
(0.380)\end{array}$ & 0.309 \\
\hline 6 & $\begin{array}{l}\text { Collecting } \\
\text { flowers and } \\
\text { fruits }\end{array}$ & $\begin{array}{l}1.609^{*} \\
(0.628)\end{array}$ & $\begin{array}{l}-0.091 \\
(0.285)\end{array}$ & $\begin{array}{l}-0.438 \\
(0.295)\end{array}$ & $\begin{array}{l}0.592 \\
(0.415)\end{array}$ & $\begin{array}{l}-0.027 \\
(0.368)\end{array}$ & -0.069 \\
\hline 7 & $\begin{array}{c}\text { Eating } \\
\text { self-collected } \\
\text { fruit }\end{array}$ & $\begin{array}{l}0.506 \\
(0.510)\end{array}$ & $\begin{array}{l}0.298 \\
(0.256)\end{array}$ & $\begin{array}{l}-0.219 \\
(0.257)\end{array}$ & $\begin{array}{l}0.427 \\
(0.365)\end{array}$ & $\begin{array}{r}-0.095 \\
(0.331)\end{array}$ & -0.018 \\
\hline 8 & $\begin{array}{l}\text { Collecting herbs } \\
\text { and weeds }\end{array}$ & $\begin{array}{c}-0.803^{*} \\
(0.348)\end{array}$ & $\begin{array}{c}0.072 \\
(0.273)\end{array}$ & $\begin{array}{c}0.036 \\
(0.267)\end{array}$ & $\begin{array}{c}0.030 \\
(0.363)\end{array}$ & $\begin{array}{l}-0.406 \\
(0.340)\end{array}$ & $0.018^{*}$ \\
\hline 9 & $\begin{array}{l}\text { Making a boat } \\
\text { from bamboo }\end{array}$ & $\begin{array}{c}-1.944^{* *} \\
(0.416)\end{array}$ & $\begin{array}{c}\mathbf{0 . 7 9 9} \\
(0.012)\end{array}$ & $\begin{array}{l}-0.244 \\
(0.332)\end{array}$ & $\begin{array}{l}-0.247 \\
(0.467)\end{array}$ & $\begin{array}{c}0.028 \\
(0.405)\end{array}$ & -0.626 \\
\hline 10 & $\begin{array}{c}\text { Making a } \\
\text { spinning top }\end{array}$ & $\begin{array}{c}-0.881^{* *} \\
(0.326)\end{array}$ & $\begin{array}{c}\mathbf{0 . 6 1 2} \\
(0.249)\end{array}$ & $\begin{array}{l}-0.382 \\
(0.253)\end{array}$ & $\begin{array}{c}0.569 \\
(0.353)\end{array}$ & $\begin{array}{r}-0.292 \\
(0.332)\end{array}$ & 0.627 \\
\hline 11 & $\begin{array}{l}\text { Making a flower } \\
\text { crown }\end{array}$ & $\begin{array}{r}-0.204 \\
(0.318)\end{array}$ & $\begin{array}{c}-\mathbf{0 . 7 4 8}^{* *} \\
(0.255)\end{array}$ & $\begin{array}{l}-0.451 \\
(0.248)\end{array}$ & $\begin{array}{l}0.134 \\
(0.351)\end{array}$ & $\begin{array}{l}-0.363 \\
(0.334)\end{array}$ & $-0.513^{* *}$ \\
\hline 12 & $\begin{array}{c}\text { Making a } \\
\text { bamboo gun }\end{array}$ & $\begin{array}{c}-1.530^{* * *} \\
(0.435)\end{array}$ & $\begin{array}{c}1.126^{* * *} \\
(0.282)\end{array}$ & $\begin{array}{l}-0.333 \\
(0.296)\end{array}$ & $\begin{array}{c}0.160 \\
(0.388)\end{array}$ & $\begin{array}{l}-0.293 \\
(0.359)\end{array}$ & 0.333 \\
\hline 13 & $\begin{array}{l}\text { Playing with soil } \\
\text { or sand }\end{array}$ & $\begin{array}{r}-0.426^{*} \\
(0.308)\end{array}$ & $\begin{array}{r}\mathbf{0 . 5 9 7} \\
(0.236)\end{array}$ & $\begin{array}{c}-\mathbf{0 . 2 7 9}^{* * *} \\
(0.249)\end{array}$ & $\begin{array}{r}-0.004 \\
(1.267)\end{array}$ & $\begin{array}{l}-0.151 \\
(1.184)\end{array}$ & 0.259 \\
\hline 14 & $\begin{array}{c}\text { Collecting seeds } \\
\text { and twigs }\end{array}$ & $\begin{array}{l}1.068 \\
(0.572)\end{array}$ & $\begin{array}{c}\mathbf{0 . 2 7 9}^{* *} \\
(0.109)\end{array}$ & $\begin{array}{c}-\mathbf{0 . 1 9 0} 0^{* * *} \\
(0.055)\end{array}$ & $\begin{array}{c}0.100 \\
(0.077)\end{array}$ & $\begin{array}{l}-0.014 \\
(0.071)\end{array}$ & 0.165 \\
\hline 15 & $\begin{array}{l}\text { Playing in rivers } \\
\text { or waterfalls }\end{array}$ & $\begin{array}{l}1.926^{*} \\
(0.500)\end{array}$ & $\begin{array}{r}\mathbf{0 . 4 1 7}^{* *} \\
(0.334)\end{array}$ & $\begin{array}{l}-0.013 \\
(0.333)\end{array}$ & $\begin{array}{c}0.289 \\
(0.428)\end{array}$ & $\begin{array}{l}0.624 \\
(0.411)\end{array}$ & -0.063 \\
\hline 16 & $\begin{array}{l}\text { Sliding on river } \\
\text { banks and } \\
\text { slopes }\end{array}$ & $\begin{array}{l}-0.418 \\
(0.343)\end{array}$ & $\begin{array}{c}1.039^{* * *} \\
(0.248)\end{array}$ & $\begin{array}{c}-0.246^{* *} \\
(0.243)\end{array}$ & $\begin{array}{c}0.039 \\
(0.343)\end{array}$ & $\begin{array}{l}0.001 \\
(0.316)\end{array}$ & 0.272 \\
\hline 17 & Making kites & $\begin{array}{c}0.155 \\
(0.389)\end{array}$ & $\begin{array}{l}\mathbf{0 . 6 1 5}^{*} \\
(0.256)\end{array}$ & $\begin{array}{c}-\mathbf{0 . 2 4 9} \\
(0.250)\end{array}$ & $\begin{array}{l}0.503 \\
(0.355)\end{array}$ & $\begin{array}{c}0.157 \\
(0.323)\end{array}$ & 0.171 \\
\hline 18 & $\begin{array}{l}\text { Participating in } \\
\text { traditional } \\
\text { outdoor games }\end{array}$ & $\begin{array}{r}-1.607^{*} \\
(0.685)\end{array}$ & $\begin{array}{l}\mathbf{1 . 0 3 2}^{*} \\
(0.345)\end{array}$ & $\begin{array}{c}-0.406 \\
(0.340)\end{array}$ & $\begin{array}{l}-0.515 \\
(0.449)\end{array}$ & $\begin{array}{r}-\mathbf{0 . 8 2 1}^{*} \\
(0.402)\end{array}$ & $-0.458^{*}$ \\
\hline $\begin{array}{r}\text { Total nu } \\
\text { acti }\end{array}$ & $\begin{array}{l}\text { of nature-related } \\
\text { experienced }\end{array}$ & $\begin{array}{l}-0.199 \\
(0.122)\end{array}$ & $\begin{array}{c}\mathbf{0 . 4 5 6}^{* * *} \\
(0.056)\end{array}$ & 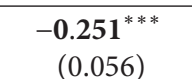 & $\begin{array}{c}0.082 \\
(0.078)\end{array}$ & $\begin{array}{l}-0.137 \\
(0.072)\end{array}$ & $-0.126^{* * *}$ \\
\hline
\end{tabular}

Significance: ${ }^{* * *} p<0.001 ;{ }^{* *} p<0.01 ;{ }^{*} p<0.05$.

\section{Discussion}

4.1. Common Nature-Related Activities in Childhood in Malaysia. The most common childhood nature-related activity in Peninsular Malaysia was playing in rivers or waterfalls. This is probably due to the tropical climate of Malaysia. In addition, children historically bathed in rivers near their house every day [33] and had direct contact with the available natural resources that were accessible near their homes. Today, Malaysians no longer use local rivers for daily baths but still use them for recreational purposes. Waterfalls in forest and nature recreational areas (e.g., Hutan Lipur) have become important places for locals to gather, play, and swim during their leisure time, especially because there is no admission fee for children under 12 years of age [36].

Observing animals was another common childhood activity. Malaysian children often observe both domestic and wild animals. For example, children used to play with 
slingshots (lastik) to shoot birds as well as catch fireflies at night and take them home [33]. In addition, Malaysian children observe domestic animals such as cows and other livestock during the Islamic festival of Eid Al-Adha. This occasion is marked most significantly by the conclusion of the annual pilgrimage to the holy city of Mecca (Haj), during which sacrificial-slaughtering (korban) of cows, goats, or buffalo takes place in mosques and the meat is distributed to those in need [37]. Wild animals that children might observe in rural areas include monkeys, gibbons, squirrels, birds, bamboo rats, smaller rodents, civets, monitor lizards, turtles, tortoises, and frogs. Children may eat fish, prawns, and crabs [38].

Collecting flowers and fruits and playing with seeds and twigs were popular nature-related activities among Malaysian children. Girls make paper dolls, design clothes for their dolls, and play cooking games (masak masak). Sometimes, children make pots and pans out of mud [39]. Children pick flowers such as lotus (Lotus spp.), tanjung (Mimusops elengi), and frangipani (Plumeria spp.) and collect fruits such as mangosteen (Garcinia mangostana), and banana (Musa paradisiaca) [34]. They help prepare tea time session by frying banana or boiling tapioca [33] throughout the year. Children eat coconut (Cocos nucifera), mango (Mangifera indica), rambutan (Nephelium lappaceum), jackfruit (Artocarpus heterophyllus), calamondin (Citrus microcarpa), and durian (Durio zibethinus) [34]. Orchards of these fruits are generally located in or near rural settlements. In addition, children explore for edible wild fruits such as langsat (Lansium aqueum) or tampoi (Baccaurea bracteata) [40] in forests during fruiting seasons.

Children use tree stems or branches to harvest fruit by tying them together with string to make a pole [40]. Twigs from rattan or small pieces of bamboo are used to make fish traps [33]. Seeds are collected from rubber trees for traditional games. For example, children play a game with rubber seeds that includes crushing the opponent's rubber seeds with their tougher rubber seeds. Other popular traditional games such as congkak or batu seremban also involve rubber seeds or small stones [33]. Observing animals and playing with seeds or other plant materials are popular among children in other countries, such as the United States $[14,41]$, Norway [42, 43], and Japan [44], although specific interactions with wild animals and plants differ greatly among countries $[45,46]$. Therefore, the common waterand tropical fruit-based activities experienced by Malaysian children can be regarded as significantly different from Western and developed countries. The popularity of playing in rivers or waterfalls (almost daily in the past) and eating a variety of self-collected fruits is considered to be unique nature activities among children in tropical countries such as Malaysia.

\subsection{Differences in Nature-Related Experiences in Childhood} among Respondents. We found little evidence that younger adults had experienced fewer nature-related activities compared to older adults, except for climbing trees and participation in traditional outdoor games. This pattern was unexpected and differed from the results of other studies (e.g., [2]). There are a few possible explanations for this. First, present research did not quantify the frequency of activities, since thought it would be difficult for respondents to provide accurate responses for activity frequency in childhood, which, in some cases, was up to 60 years ago. Even though younger people had experienced most of the same activities, they may have participated in these activities less frequently than older people. Second, the specifics of each activity may have differed among generations, and our survey was not designed to reveal the details of each activity. For example, older generations may have typically observed wild or livestock animals, while younger generations in urban areas may have observed pets or exotic animals in zoos. A more detailed analysis on the types of activities and interactions with animals and plants is necessary to understand the changes in interactions with nature among children in Malaysia.

Furthermore, attitudes toward nature may have changed due to changes in the Malaysian education system. The Malaysia Ministry of Education has incorporated the Environmental Education Program into the Malaysian school curriculum since 1986 in both primary and secondary schools [47], which aims to enhance the awareness of environmental issues in children and provide chances to interact with nature outdoors. Kindergarten and primary schools are becoming more important for providing nature experiences for children. Meanwhile, significantly fewer people who grew up in urban areas had experiences in six of the nature-related activities compared to people who grew up in rural areas. This suggests that childhood setting affected the respondents' activities and experiences. Similarly, rural children reported having more active involvement in nature-related activities than urban children in South Carolina, United States [48, 49], and the United Kingdom [50,51]. The significant interaction of age and childhood settings indicates that young and middle-aged people with urban childhood had more decline in nature-related activities than rural people as presented in result section (Figure 3). This is consistent with our hypothesis that natural environments are becoming less available to urban people than rural people, but other factors such as parental concern about safety [52], fear in crime [53], and screen-based entertainment [45] could also affect children's outdoor play. Combination of these natural and social environments in urban areas is possibly leading to a decline of experiences with nature among urban children in Malaysia.

About 70\% of Southeast Asian children now play mobile games in their spare time, compared to $56 \%$ in the United States. In Association of Southeast Asian Nations (ASEAN) countries such as Indonesia, Singapore, Vietnam, Thailand, and Malaysia, children have shown changes in play trends, especially those in urban areas, and attraction to screenbased entertainment and gadgets (e.g., internet and online games) has increased [54]. Therefore, it is important to monitor changes in children's experiences related to nature and how these changes affect their physical and mental health and attitudes toward nature. Public spaces in Malaysia [55] are being transformed into better playing spaces by 
local stakeholders and state city councils [56], which provide opportunities for direct contact with elements of nature (e.g., plants, soil, and animals) and nature-related experiences for children in urban areas [57]. However, many urban parks in developing countries are being designed similar to those in Western countries $[34,58,59]$. Since climates, cultures, and popular nature-related activities differ in tropical developing countries, public space and urban park designs should reflect these factors. Our results suggest that childhood nature activities such as playing in fresh water, observing animals, collecting tropical fruits, and other plant materials are particularly popular among children in Malaysia, and spaces for these activities would likely be well-accepted by local residents. Furthermore, some activities, including tree climbing, fishing, and playing with silts, are less popular among people who grew up in urban areas than those who grew up in rural areas. Creating spaces for these activities is important for mitigating the decline in nature-related activities among urban children. Reconnecting urban children with nature is becoming increasingly important for urban planning and environmental education in tropical developing countries such as Malaysia.

\section{Conclusion}

This is the first study to document common nature-related activities experienced in childhood in Malaysia. Playing in rivers or waterfalls, observing animals, collecting flowers and fruits, collecting seeds and twigs, and eating self-collected fruit were identified as the most common activities experienced in childhood. Although the percentage of respondents who experienced each activity did not differ significantly among generations, people who grew up in rural areas experienced more activities than those who grew up in urban areas. Therefore, increases in urbanization and population density in urban areas may cause a decline in nature-related experiences in the future. Efforts to create urban parks and other public spaces to enable urban children to reconnect with nature will become an increasingly important for urban planning and environmental education in tropical developing countries such as Malaysia.

\section{Conflicts of Interest}

The authors declare no conflicts of interest associated with this manuscript.

\section{Acknowledgments}

The research presented in this paper was funded by the Tokyo Metropolitan Government. Thanks are due to the research team at Forest Research Institute Malaysia (FRIM) particularly from Environmental Education Unit of the Ecotourism and Urban Forestry Programme for their full support with the questionnaire survey, Mrs. Nik Azyyati, Mrs. Naimah, and Mrs. Fatin. The authors thank kind research assistants, Mrs. Alia and Mrs. Fazlina, for their time in data compiling and data validation.

\section{References}

[1] J. R. Miller, "Biodiversity conservation and the extinction of experience," Trends in Ecology and Evolution, vol. 20, no. 8, pp. 430-434, 2005.

[2] M. Soga and K. J. Gaston, "Extinction of experience: The loss of human-nature interactions," Frontiers in Ecology and the Environment, vol. 14, no. 2, pp. 94-101, 2016.

[3] P. A. Zaradic and O. R. W. Pergams, "JDP FORUM Videophilia: implications for childhood cevelopment and conservation," Journal of Developmental Processes, vol. 2, no. 1, pp. 130-144, 2007.

[4] C. J. Maller, "Promoting children's mental, emotional and social health through contact with nature: A model," Health Education, vol. 109, no. 6, pp. 522-543, 2009.

[5] D. W. Rajecki, Attitudes: Themes and Advances, Sinauer, Sunderland, Mass, USA, 1982.

[6] S. de Vries, R. A. Verheij, P. P. Groenewegen, and P. Spreeuwenberg, "Natural environments-healthy environments? An exploratory analysis of the relationship between greenspace and health," Environment and Planning A, vol. 35, no. 10, pp. 17171731, 2003.

[7] R. Ewing, "Can the physical environment determine physical activity levels?" Exercise and Sport Sciences Reviews, vol. 33, no. 2, pp. 69-75, 2005.

[8] N. Humpel, N. Owen, and E. Leslie, "Environmental factors associated with adults' participation in physical activity: a review," The American Journal of Preventive Medicine, vol. 22, no. 3, pp. 188-199, 2002.

[9] T. Takano, K. Nakamura, and M. Watanabe, "Urban residential environments and senior citizens' longevity in megacity areas: The importance of walkable green spaces," Journal of Epidemiology and Community Health, vol. 56, no. 12, pp. 913-918, 2002.

[10] C. W. Thompson, P. Aspinall, and A. Montarzino, "The childhood factor: Adult visits to green places and the significance of childhood experience," Environment and Behavior, vol. 40, no. 1, pp. 111-143, 2008.

[11] K. Lloyd, J. Burden, and J. Kiewa, "Young girls and urban parks: planning for transition through adolescence," Journal of Parks and Recreation Administration, vol. 26, pp. 21-38, 2008.

[12] I. E. Palmberg and J. Kuru, "Outdoor activities as a basis for environmental responsibility," The Journal of Environmental Education, vol. 31, no. 4, pp. 32-36, 2000.

[13] L. Chawla, "Growing up green: becoming an agent of care for the natural world," Journal of Developmental Processes, vol. 4, no. 1, pp. 6-23, 2009.

[14] N. Wells and K. Lekies, "Nature and the life course: pathways from childhood nature experiences to adult environmentalism: children," Youth and Environments, vol. 16, no. 1, pp. 1-24, 2006.

[15] V. I. Lohr and C. H. Pearson-Mims, "Children's active and passive interactions with plants influence their attitudes and actions toward trees and gardening as adults," HortTechnology, vol. 15, no. 3, pp. 472-476, 2005.

[16] L. Chawla, "Life paths into effective environmental action," The Journal of Environmental Education, vol. 31, no. 1, pp. 15-26, 1999.

[17] L. Chawla and D. F. Cushing, "Education for strategic environmental behavior," Environmental Education Research, vol. 13, no. 4, pp. 437-452, 2007.

[18] N. S. Sodhi, L. P. Koh, B. W. Brook, and P. K. L. Ng, "Southeast Asian biodiversity: An impending disaster," Trends in Ecology and Evolution, vol. 19, no. 12, pp. 654-660, 2004. 
[19] Secretariat of the Convention on Biological Diversity, "Global Diversity Outlook," 2001, https://www.cbd.int/gbo/.

[20] Department of Statistics Malaysia, "Population and demography," 2006, https://www.statistics.gov.my/.

[21] J. R. Vincent and Y. Hadi, Malaysia: Sustainable Agriculture and the Environment in the Humid Tropics: National Research Council (ed), National Academy Press, Washington, DC, USA, 1993.

[22] National Physical Plan, “The National Physical Plan: Federal Department of Town and Country Planning, Ministry of Housing and Local Government, Malaysia," 2005.

[23] S. A. Abdullah and N. Nakagoshi, "Changes in landscape spatial pattern in the highly developing state of Selangor, peninsular Malaysia," Landscape and Urban Planning, vol. 77, no. 3, pp. 263275, 2006.

[24] U. Yaakob, T. Masron, and F. Masami, "Ninety years of urbanization in Malaysia: a geographical investigation of its trends and characteristics," Journal of Ritsumeikan Social Sciences and Humanities, vol. 4, no. 3, pp. 79-101, 2010.

[25] National Policy on Biological Diversity 2016-2025, Ministry of Natural Resources and Environment (NRE), Putrajaya, Malaysia, 2016.

[26] Convention on Biological Diversity: Malaysia’s 5th Report to Convention on Biological Diversity, 2016, https://www.cbd.int/ doc/world/my/my-nr-05-en.pdf.

[27] C. P. Lim, "Changes in the Malaysian economy and trade trends and prospects: Trade and Structural Change in Pacific Asia, National Bureau of Economic Research, Inc," 435-466, 1987, http://EconPapers.repec.org/RePEc:nbr:nberch:6931.

[28] S. A. Abdullah and A. A. Hezri, "From forest landscape to agricultural landscape in the developing tropical country of Malaysia: Pattern, process, and their significance on policy," Environmental Management, vol. 42, no. 5, pp. 907-917, 2008.

[29] M. Miyamoto, M. Mohd Parid, Z. Noor Aini, and T. Michinaka, "Proximate and underlying causes of forest cover change in Peninsular Malaysia," Forest Policy and Economics, vol. 44, pp. 18-25, 2014.

[30] Department Statistics of Malaysia, "Chapter 2: Population and housing census, para. 1 to 3," 2015, https://www.statistics .gov.my.

[31] Malaysia Rural Master Plan, "Rural Expedition And Discovery," 2010, http://ruralexpedition.blogspot.jp/2010/12/malaysia-ruraldefinition.html.

[32] Traditional games in Malaysia, 2016, http://traditionalgamescct .blogspot.my/2013/03/galah-panjang.html.

[33] M. N. k. Lat, Kampung Boy, Berita Publishing, Kuala Lumpur, Malaysia, 2006.

[34] J. Abu Bakar, A design guide for public parks in Malaysia, University of Technology Malaysia Press, Kuala Lumpur, Malaysia, 2002.

[35] R Core Team, "R: A language and environment for statistical computing. Tokyo, Japan: The R Foundation for Statistical Computing," 2015, http://www.R-project.org.

[36] Forestry Department Peninsular Malaysia, "Amenity forests and state park forests: Forestry Department Peninsular Malaysia, Kuala Lumpur, Malaysia," 2016, https://www.forestry.gov.my/ index.php/en/2016-06-07-02-31-39/2016-06-07-02-35-17/amenity-forests-state-park-forests.

[37] S. Nelly, "Malaysia: Festivals and Celebrations in Malaysia," 2012, http://www.thestar.com.my/travel/malaysia/2012/11/12/ festivals-and-celebrations-in-malaysia/.
[38] K. Endicott and P. Bellwood, "The possibility of independent foraging in the rain forest of Peninsular Malaysia," Human Ecology, vol. 19, no. 2, pp. 151-185, 1991.

[39] B. S. H. Lee, "Life Moments from a Childhood in the 60s," 2014, http://www.thestar.com.my/lifestyle/features/2014/10/24/lifemoments-from-a-childhood-in-the-60s/.

[40] I. Said, "Affordances of nearby forest and orchard on children's performances," Procedia-Social and Behavioral Sciences, vol. 38, pp. 195-203, 2012.

[41] S. R. Kellert and M. O. Westervelt, "Children's attitudes, knowledge and behaviors towards animals," Childrens Environments Quarterly, vol. 1, pp. 8-11, 1984.

[42] T. Bjerke and T. Østdahl, "Animal-related attitudes and activities in an urban population," Anthrozoos, vol. 17, no. 2, pp. 109-129, 2004.

[43] T. Bjerke, B. P. Kaltenbom, and T. S. Ødegårdstuen, “Animalrelated activities and appreciation of animals among children and adolescents," Anthrozoos, vol. 14, no. 2, pp. 86-94, 2001.

[44] T. Hosaka, K. Sugimoto, and S. Numata, "Effects of childhood experience with nature on tolerance of urban residents toward hornets and wild boars in Japan," One PloS, vol. 12, no. 4 article e0175243, 2017.

[45] M. Soga, K. J. Gaston, Y. Yamaura, K. Kurisu, and K. Hanaki, "Both direct and vicarious experiences of nature affect children's willingness to conserve biodiversity," International Journal of Environmental Research and Public Health, vol. 13, no. 6, article 529, 2016.

[46] W. Zhang, E. Goodale, and J. Chen, "How contact with nature affects children's biophilia, biophobia and conservation attitude in China," Biological Conservation, vol. 177, pp. 109-116, 2014.

[47] M. Aini, S. Nor Azura, and A. Fakhru'l-Razi, "Impact of environmental education on concern, knowledge and sustainable behavior of primary school children," Health and the Environment Journal, vol. 2, no. 1, pp. 50-53, 2011.

[48] G. M. Felton, M. Dowda, D. S. Ward et al., "Differences in physical activity between black and white girls living in rural and urban areas," Journal of School Health, vol. 72, no. 6, pp. 250-255, 2002.

[49] K. K. Davison and C. T. Lawson, "Do attributes in the physical environment influence children's physical activity?: a review of the literature," International Journal of Behavioral Nutrition and Physical Activity, vol. 3, no. 19, pp. 1-17, 2006.

[50] C. Ward, The Child in the Country, Bedford Square Press, London, UK, 1988.

[51] C. Ward, The Child in the City, Bedford Square Press, London, UK, 1990.

[52] G. Valentine and J. McKendrick, "Children's outdoor play: exploring parental concerns about children's safety and the changing nature of childhood," Geoforum, vol. 28, no. 2, pp. 219235, 1997.

[53] S. Maruthaveeran and C. K. Van den Bosh, "Fear of crime in urban parks - What the residents of Kuala Lumpur have to say?" Urban Forestry and Urban Greening, vol. 14, no. 3, pp. 702-713, 2015.

[54] Venture Beat, "Changing Pattern of Children-Play in Southeast Asia," 2016, http://venturebeat.com/2016/01/13/southeast-asiankids-are-20-more-active-on-mobile-than-u-s-kids/.

[55] N. Z. Harun and I. Said, The Changing Roles of Public Spaces in Malaysia, Habitat Magazine, Ministry of Housing and Local Governments, 2009. 
[56] M. F. Latfi and H. A. Karim, "Suitability of Planning guidelines for children playing spaces," Procedia - Social and Behavioral Sciences, vol. 38, pp. 304-314, 2012.

[57] N. A. Malek, M. Mariapan, and N. I. Rahman, "Community participation in quality assessment for green open spaces in Malaysia," Procedia - Social and Behavioral Sciences, vol. 168, pp. 219-228, 2015.

[58] R. S. Rabare, R. Okech, and G. M. Onyango, "The role of urban parks and socio-economic development: case study of Kisumu, Kenya," Theoretical and Empirical Researches in Urban Management, vol. 3, no. 12, pp. 22-36, 2009.

[59] S. Abendroth, I. Kowarik, N. Müller, and M. Von der Lippe, "The green colonial heritage: Woody plants in parks of Bandung, Indonesia," Landscape and Urban Planning, vol. 106, no. 1, pp. 12-22, 2012. 


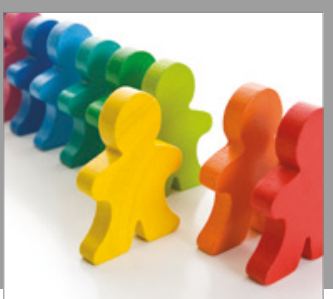

Autism

Research and Treatment
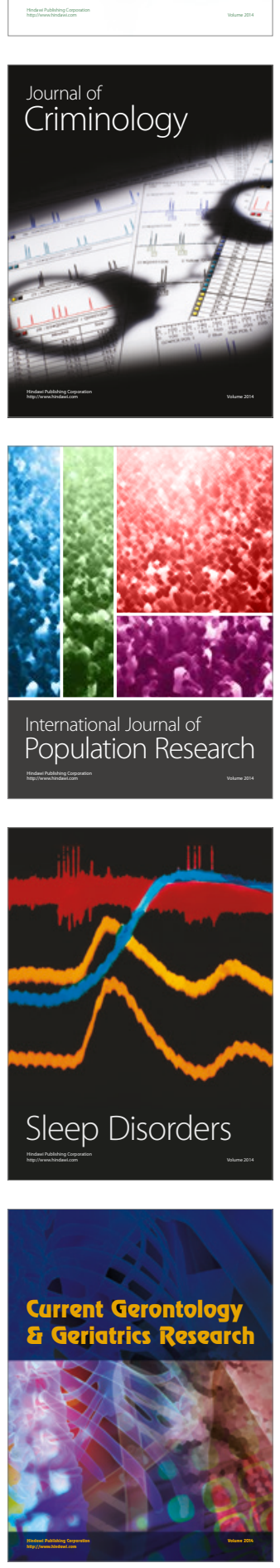

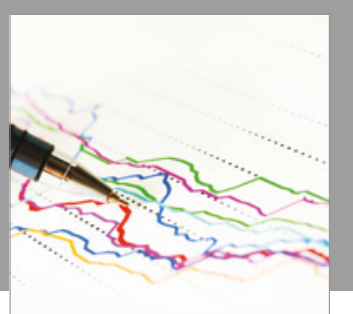

Economics

Research International

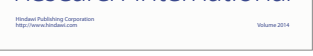

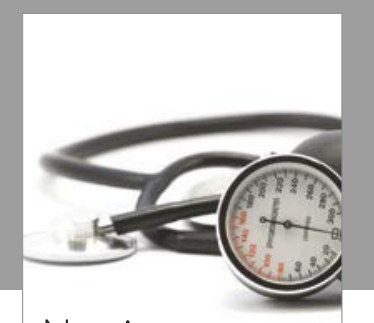

Nursing

Research and Practice

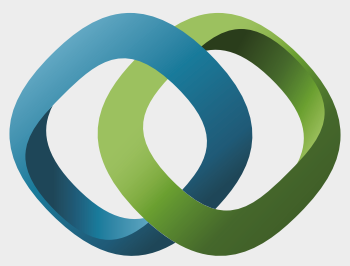

\section{Hindawi}

Submit your manuscripts at

https://www.hindawi.com
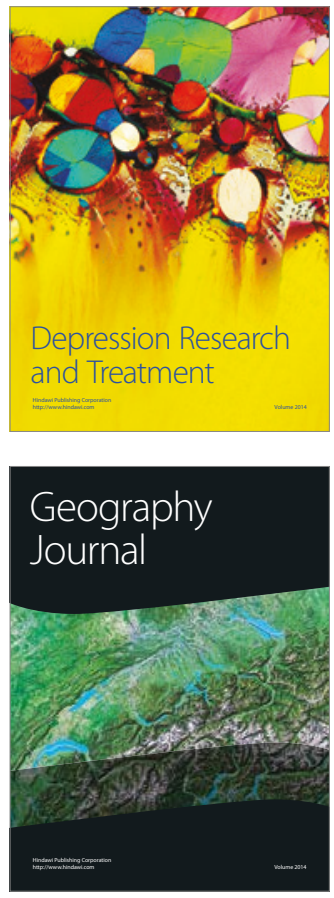
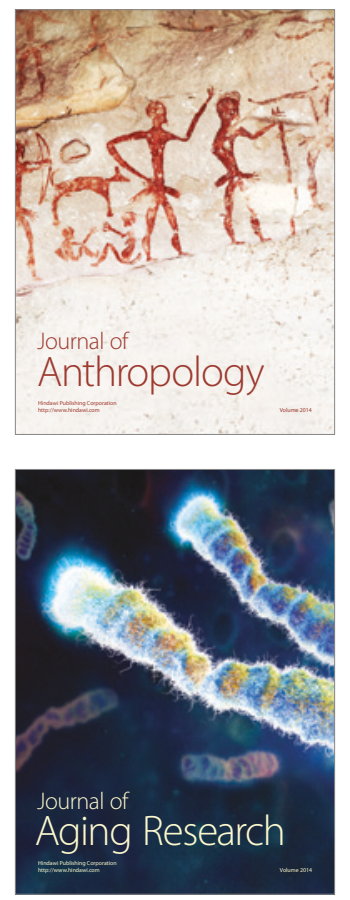
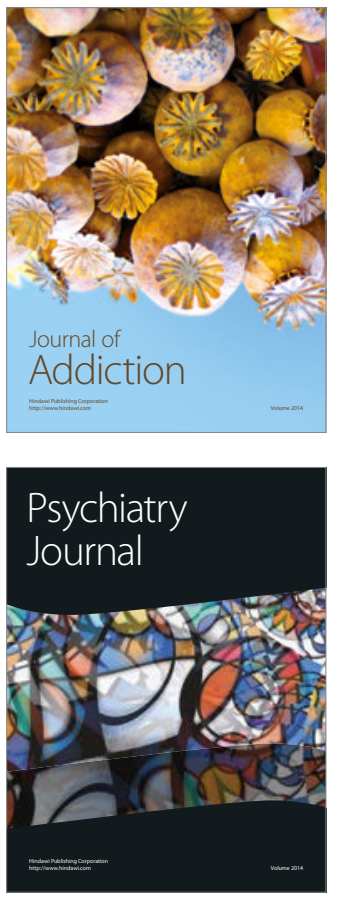

Child Development

Research

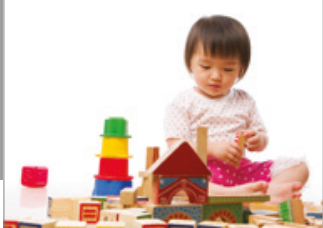

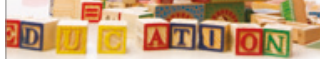
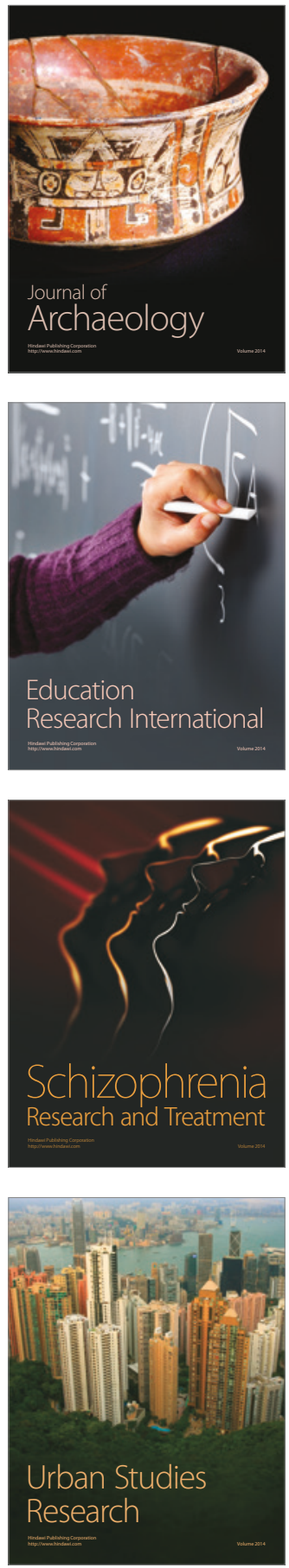